\title{
PEMETAAN INDUSTRI KREATIF DAN PENENTUAN KOMPETENSI INTI BANGKALAN
}

\author{
FITRI AGUSTINA, NACHNUL ANSORI, DAN TEGAR PRADANA F.A \\ Progaram Studi Teknik Industri, Universitas Trunojoyo Madura \\ Jl. Raya Telang Po Box 2 Kamal, Bangkalan Madura 69162, Indonesia \\ E-mail: fitri_agoesti@yahoo.co.id, nachnul@gmail.com
}

\begin{abstract}
ABSTRAK
Penentuan kompetensi inti industri kreatif yang bercirikan pemanfaatan kreatifitas, ketrampilan serta bakat individu merupakan proses pemilihan yang sangat krusial. Hal ini dikarenakan output dari industri kreatif berupa produk ataupun pemanfaatan daya kreasi dan daya cipta individu yang semakin variatif dan berkembang. Untuk bisa melakukan penentuan kompetensi inti maka dilakukan pemetaan industri kreatif terlebih dahulu. Kajian dalam penelitian ini berupa pemetaan industri kreatif beserta penentuan kompetensi inti industri kreatif Kabupaten Bangkalan berdasarkan multi-kriteria pada variabel produk domestik bruto (PDB), jumlah ketenagakerjaan, perdagangan internasional dan jumlah perusahaan. Metode yang digunakan berupa integrasi Analytical Hierarchy Process (AHP) dan metode perankingan Preference Ranking Organization Method for Enrichment Evaluation (PROMETHEE). Hasil yang didapatkan dari pemetaan industri kreatif di Bangkalan terdiri dari subsektor pasar seni dan barang antik, kerajinan, desain fesyen, video/film dan fotografi serta penerbitan dan percetakan. Sedangkan subsektor kerajinan dipilih sebagai kompetensi inti yang diunggulkan.
\end{abstract}

Kata kunci: industri kreatif, kompetensi inti daerah, MCDM, AHP, PROMETHEE

\begin{abstract}
Determining core competence for creative industry which is characterized by utilizing creativity, skill and individual talent is the crucial selection process. It is because the output of creative industry as well as products and utilization of creativity are rapidly developed. This research discusses about mapping creative industry and determining core competence for creative industry in Bangkalan district based on the variable of gross domestic product, number of worker, international trade and number of firm. The method adopted for core competence determination is an integrated Analytical Hierarchy Process (AHP) and Preference Ranking Organization Method for Enrichment Evaluation (PROMETHEE). The result of mapping creative industry shows that art, craft, design, video or film and publishing are included in it. Meanwhile craft subsector is determined as a core competence that is focused in Bangkalan district.
\end{abstract}

Keywords: creative industry, core competence, MCDM, AHP, PROMETHEE

\section{PENDAHULUAN}

Pemerintah Indonesia sekarang ini giat mensosialisasikan ekonomi kreatif guna mengurangi angka pengangguran oleh karena industri kreatif ramah lingkungan dan sangat menjanjikan untuk jangka panjang. Menurut Sumotarto (2010), industri kreatif adalah bentuk pemanfaatan kreatifitas, keterampilan serta bakat individu dengan cara menghasilkan dan mengeksploitasi daya kreasi dan daya cipta individu. Peningkatan kreativitas dan ide baru dalam masyarakat, diupayakan mendorong berkembangnya industri kreatif di berbagai penjuru nusantara. Hal ini sejalan dengan visi ekonomi kreatif Indonesia dalam menghasilkan bangsa yang berkualitas hidup dan bercitra kreatif di mata dunia, sedangkan pemberdayaan sumber daya insani sebagai modal utama pembangunan nasional sebagai amanah misi yang diembannya. Menurut Departemen Perdagangan Republik Indonesia (2008), industri kreatif terbagi menjadi empat belas subsektor industri yakni 
1) Periklanan, 2) Arsitektur, 3) Pasar Barang Seni, 4) Kerajinan, 5) Desain, 6) Fesyen, 7) Video, Film, dan Fotografi, 8) Permainan Interaktif, 9) Musik, 10) Seni Pertunjukan, 11) Penerbitan dan Percetakan, 12) Layanan Komputer dan Piranti Lunak, 13) Televisi dan Radio, serta 14) Riset dan Pengembangan.

Perkembangan industri kreatif di Indonesia masih terkategori mandul walaupun memiliki potensi sumber daya manusia yang cukup teruji di dunia internasional. Perkembangan industri kreatif berada pada kisaran $9 \%$ pertahun akan tetapi tidak menghasilkan karya, sehingga tidak menghasilkan nilai ekonomi dan nilai estetika baru (Liang, 2013). Salah satu elemen penting dalam mewujudkan industri kreatif menjadi motor kebangkitan ekonomi kreatif di Indonesia adalah dengan pembentukan roadmap industri kreatif dengan melakukan pemetaan potensi industri kreatifnya pada masing-masing subsektornya. Hal ini dikarenakan bisnis kreatif merupakan usaha yang berbasis kreatifitas dan ketrampilan individu yang menghasilkan keunikan suatu produk atau jasa (Darwanto, 2012).

Pulau Madura adalah salah satu wilayah di Jawa Timur yang memiliki industri kreatif yang sangat bervariasi. Produksi Madura memberi kontribusi sebesar $11 \%$ dari total produksi di Jawa Timur yang terbesar dari produksi garam. Aktivitas ekonomi di Madura hampir 90\% dilakukan oleh usaha mikro, kecil, dan menengah (UMKM). Berdasarkan data Dinas Perindustrian dan Perdagangan (Disperindag) Jawa Timur, di Madura terdapat setidaknya 68.733 unit industri kecil menengah yang tersebar di Sumenep sejumlah 34.173 unit dan Bangkalan sebanyak 17.666 unit. Dari data tersebut seharusnya dapat diidentifikasi bahwa Bangkalan merupakan salah satu kabupaten yang mempuyai sektor industri mikro kecil menengah yang sangat banyak dan bervariatif.

Banyaknya potensi industri mikro kecil menengah (IMKM) yang ada di kabupaten Bangkalan, perlu dilakukan adanya pengklasifikasian atau pemetaan industri berdasarkan empat belas klasifikasi industri kreatif yang telah ditentukan oleh Departemen Perdagangan Republik Indonesia. Adanya pemetaan tersebut diharapkan kebijakan pemerintah untuk meningkatkan daya saing industri kreatif bisa lebih terarah dan berkelanjutan sesuai dengan keunggulan/ kekhasan yang dimiliki. Menurut Pono (2010) untuk mendorong terjadinya akumulasi pembelajaran dalam peningkatan daya saing, perlu ditentukan kompetensi inti daerah berdasarkan kemampuan dan sumber daya yang dikelola secara terintegrasi, oleh karena membangun kompetensi inti daerah berarti melakukan pembinaan dalam rangka meningkatkan daya saing produk yang dihasilkan oleh suatu daerah untuk meningkatkan nilai tambah ekonomi daerah agar lebih terarah, efesien, dan efektif. Sejalan dengan penelitian Indahsari (2010) bahwa salah satu caranya adalah dengan model penentuan prioritas unggulan daerah yang bisa dilakukan dengan cara mengetahui produk andalan daerahnya.

Alasan mengapa penting dan perlu dilakukan pemetaan subsektor dan penentuan kompetensi inti industri kreatif, hal ini dikarenakan sektor industri kreatif memiliki kontribusi ekonomi yang signifikan bagi perekonomian Indonesia, dapat menciptakan iklim bisnis yang positif, dapat memperkuat citra dan identitas bangsa, mendukung pemanfaatan sumber daya yang terbarukan, merupakan pusat penciptaan inovasi dan pembentukan kreativitas dan memiliki dampak social yang positif. Pemilihan subsektor yang diunggulkan dapat juga dimaksudkan sebagai pemberian prioritas untuk dilakukannya inovasi sistem pada industri kreatif dalam memelihara pengetahuan, rekayasa dan teknologi, serta budaya untuk mewujudkan industri kreatif melalui peningkatkan dinamika dan perbaikan kebijakan pengembangan daerah (Cunningham, 2004). Dalam perspektif ekonomi regional, kompetensi inti adalah sekumpulan kemampuan terintegrasi yang dimiliki daerah untuk dapat membangun daya saing daerahnya dengan keunikan yang dimiliki oleh daerah. Oleh karena dewasa ini pengembangan daerah 
dilakukan melalui pengembangan sektor industri yang menjadi unggulan daerah tersebut (Nurcahyo dkk., 2012). Selain itu dengan penentuan kompetensi inti berarti pembinaan lebih fokus, efisien, dan efektif sesuai dengan potensi daerah untuk meningkatkan daya saing produk yang dihasilkan.

\section{METODE}

Pemetaan industri kreatif dilakukan berdasarkan empat belas subsektor industri kreatif. Hal ini didasarkan pada hasil studi industri kreatif Indonesia oleh Departemen Perdagangan (2007) didapatkan 14 subsektor industri kreatif atas klasifikasi baku usaha industri Indonesia bahwa kontribusi industri kreatif terhadap perekonomian Indonesia dapat dibedakan menjadi lima indikator utama antara lain PDB, jumlah ketenagakerjaan, perdagangan internasional, jumlah perusahaan dan dampak terhadap sektor lain. Olehkarenanya dalam penelitian ini dilakukannya pemetaan dan penentuan produkproduk yang diunggulkan berupa subsektor industri kreatif yang diprioritaskan dari empat belas subsektor industri kreatif berdasarkan pertimbangan variabel pada Klasifikasi Buku Lapangan Indonesia (KBLI) berupa PDB, jumlah ketenagakerjaan, perdagangan internasional dan jumlah perusahaan. Namun pada penelitian ini indikator pengaruh terhadap sektor lain tidak dipertimbangkan dengan alasan fokus penentuan dan pemetaan hanya dalam ruang lingkup sektor industri kreatif saja.

Sumber data yang digunakan dalam penelitian adalah data primer dan data sekunder. Data primer diperoleh dengan melakukan wawancara dan angket/kuisioner kepada pakar dalam bidang industri kreatif dan UKM di Kabupaten Bangkalan. Data sekunder diperoleh dan dikumpulkan dari data Badan Pusat Statistik dan Dinas Perindustrian dan Perdagangan (Disperindag) Kabupaten Bangkalan. Pemetaan subsektor industri kreatif dilakukan dengan melakukan inventarisasi data berupa data sekunder yang diambil mulai tahun 2009 sampai dengan 2011. Data tiga tahun yang diambil berturut-turut sebagai pembanding untuk menggambarkan pola pertumbuhan masingmasing subsektor industri kreatif. Dari hasil pemetaan akan diketahui jenis-jenis industri kreatif yang ada pada masing-masing subsektor industri kreatif di Bangkalan beserta informasi kontribusi PDB yang dihitung dengan pendekatan nilai tambah produksi, jumlah ketenaga kerja yang ditentukan berdasarkan jumlah tenaga kerja yang dipekerjakan, nilai produk ekspor berdasarkan nilai jual ekspor produk dan jumlah perusahaan berdasarkan jumlah perusahaan yang secara aktif masih terdaftar di Disperindag selama tiga tahun.

Setelah diketahui pemetaan industri kreatif yang ada di Kabupaten Bangkalan pada empat belas subsektor, selanjutnya dilakukan pemilihan subsektor unggulan berdasarkan pemetaan kompetensi inti daerah di kabupaten Bangkalan dengan menggunakan integrasi metode AHP dan PROMETHEE. Pembobotan pada AHP dilakukan untuk memudahkan pengambilan keputusan karena pengambil keputusan memiliki keterbatasan kognitif dan keterbatasan pemikiran (Nurcahyo dkk, 2012). Sedangkan metode PROMETHEE merupakan pengambilan keputusan atas suatu masalah yang memiliki lebih dari satu kriteria (multikriteria) yang memiliki nilai preferensi. Integrasi AHP-PROMETHEE terletak pada penggunaan tool AHP untuk melakukan pembobotan pada bobot kriteria PROMETHEE dengan mempertimbangkan kriteria pada empat variabel hasil pemetaan yang telah dilakukan berupa produk domestik bruto, jumlah pekerja, perdagangan internasional dan jumlah perusahaan. Sedangkan PROMETHEE sendiri digunakan untuk melakukan perankingan terhadap indikator capaian empat variabel berdasarkan pertimbangan tipe preferensi III yaitu V shape function.

Pembobotan dengan AHP dilakukan dengan melakukan perbandingan berpasangan terhadap empat variabel yang pengambilan datanya diperoleh dengan melibatkan tim ahli dari Dinas Koperasi dan UMKM serta Dinas Perindustrian dan Perdagangan Kabupaten 
Bangkalan. Evaluasi pada PROMETHEE dengan menggunakan data nilai kontribusi hasil pada empat variabel sebelumnya dengan memasukkan bobot yang dihasilkan dari AHP. Evaluasi menggunakan bantuan software dicision lab 2000. Dari hasil output software akan diketahui nilai net flow sebagai indikator subsektor yang dijadikan kompetensi intinya.

\section{HASIL DAN PEMBAHASAN}

Hasil pemetaan industri kreatif Kabupaten Bangkalan diperoleh profil dan pemetaan industri kreatif tahun 2009 sampai dengan tahun 2011 yang mencakup empat belas subsektor. Profil merupakan subsektor yang teridentifikasi sedangkan pemetaan berupa jenis industri kreatif yang ada pada tiap subsektor (Huda dkk., 2013). Dari profil dan pemetaan empat belas sektor yang diidentifikasi ternyata hanya terdapat lima subsektor industri kreatif di Kabupaten Bangkalan, sedangkan sembilan subsektor yang lain tidak ada seperti ditunjukkan pada Tabel 1.

Berdasarkan Tabel 1, profil dan pemetaan diperoleh hasil yang tidak berbeda secara signifikan, di mana subsektor yang tumbuh dan berkembang hanya ada pada subsektor pasar barang seni dan antik, kerajinan, desain fesyen, video/film dan fotografi serta penerbitan/ percetakan. Artinya pertumbuhan jenis industri kreatif dari tahun 2009 sampai dengan 2011 tidak ada perbedaan yang cukup berarti. Selain itu secara detail hasil pemetaan pertumbuhan PDB pada subsektor kerajinan mengalami pertumbuhan yang cukup signifikan dari tahun 2010 ke tahun 2011 sebesar 28\%. Sedangkan pertumbuhan nilai PDB pada tahun 2009 ke tahun 2010 hampir tidak mengalami pertumbuhan yang signifikan. Berbeda dengan tahun 2010 ke tahun 2011 mengalami pertumbuhan signifikan, hal ini dapat disimpulkan bahwa untuk subsektor kerajinan adalah bidang yang cukup menjanjikan untuk dikembangkan seperti pada Gambar 1. Fluktuasinya PDB yang terjadi mengindikasikan adanya perubahan pertumbuhan subsektor industri kreatif, di mana pada umumya berkurangnya jumlah subsector

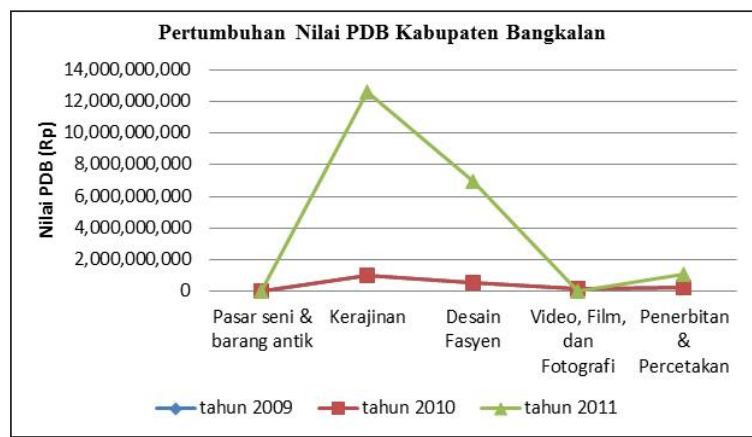

Gambar 1. Pertumbuhan nilai PDB kabupaten Bangkalan

Tabel 1. Profil dan Pemetaan Industri Kreatif

\begin{tabular}{|c|c|c|c|}
\hline \multirow{2}{*}{ Profil } & \multicolumn{3}{|c|}{ Jenis Industri } \\
\hline & 2009 & 2010 & 2011 \\
\hline $\begin{array}{l}\text { Pasar Barang } \\
\text { Seni dan Antik }\end{array}$ & Souvenir & Souvenir & Souvenir \\
\hline Kerajinan & $\begin{array}{l}\text { Emban Cincin, Gedek, } \\
\text { Kusen Kayu, Kerajinan } \\
\text { Batuan, Pecut, Perahu } \\
\text { Kayu, Perhiasan, } \\
\text { Mebel, Tikar }\end{array}$ & $\begin{array}{l}\text { Emban Cincin, Gedek, } \\
\text { Kusen Kayu, Kerajinan } \\
\text { Batuan, Pecut, Perahu Kayu, } \\
\text { Perhiasan, Mebel, Tikar }\end{array}$ & $\begin{array}{l}\text { Emban Cincin, Gedek, } \\
\text { Kusen Kayu, Kerajinan } \\
\text { Batuan, Pecut, Perahu } \\
\text { Kayu, Perhiasan, Mebel, } \\
\text { Tikar }\end{array}$ \\
\hline Desain Fesyen & Batik, Konveksi, Bordir & Batik, Konveksi, Bordir & Batik, Konveksi, Bordir \\
\hline $\begin{array}{l}\text { Video, Film dan } \\
\text { Fotografi }\end{array}$ & $\begin{array}{l}\text { Jasa Pengadaan Film, } \\
\text { Jasa Cuci Cetak }\end{array}$ & $\begin{array}{l}\text { Jasa Pengadaan Film, Jasa } \\
\text { Cuci Cetak }\end{array}$ & Jasa Cuci Cetak \\
\hline $\begin{array}{l}\text { Penerbitan } \\
\text { Percetakan }\end{array}$ & Percetakan & Percetakan & Percetakan \\
\hline
\end{tabular}




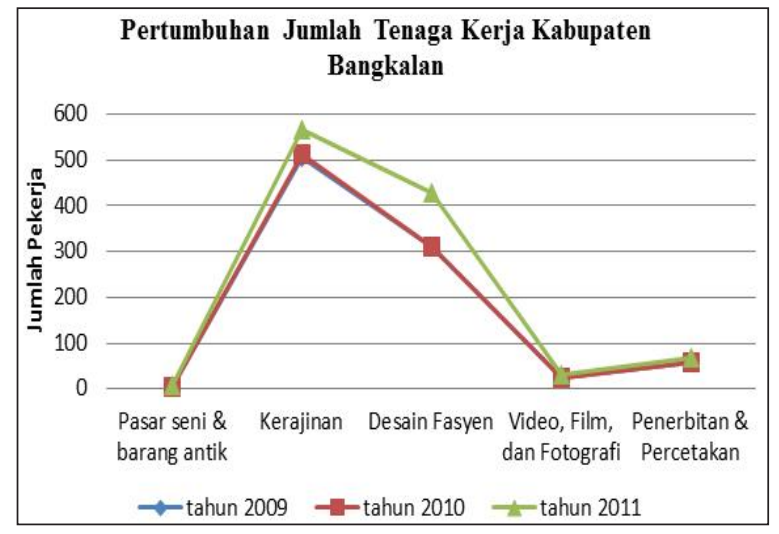

Gambar 2. Pertumbuhan jumlah tenaga kerja kabupaten Bangkalan

industri dikarenakan ketidakmampuan subsektor untuk membiayai dirinya sendiri (survive).

Pertumbuhan Jumlah Tenaga Kerja (Growth of Employment/GE) industri kreatif adalah besaran yang menunjukkan pertumbuhan penyerapan tenaga kerja tahunan Industri Kreatif. Semakin tinggi growth of employment mengindikasikan semakin baik pertumbuhan industri dari tahun ke tahun, sehingga memerlukan tambahan penyerapan tenaga kerja. Pada Gambar 2 ditunjukkan kondisi pertumbuhan jumlah tenaga kerja pada tahun 2009 sampai dengan tahun 2011. Kondisi pertumbuhan tenaga kerja pada tahun 2009 dan tahun 2010 memiliki angka yang sama sehingga pada grafik tidak kelihatan nampak. Hal ini disebabkan oleh karena tidak adanya pertambahan maupun pengurangan jumlah tenaga yang dipekerjakan pada tahun tersebut.

Pertumbuhan tahunan nilai ekspor industri kreatif merupakan persentase perubahan nilai ekspor dalam periode satu tahun terhadap tahun dasarnya. Perubahan nilai ekspor annual growth setidaknya mencerminkan dua hal yaitu kinerja industri dan potensinya. Semakin tinggi annual growth maka semakin baik kinerja industri kreatif dalam perekonomian nasional dan semakin besar potensinya untuk dikembangkan.

Sementara pertumbuhan tahunan jumlah perusahaan di industri kreatif merupakan persentase perubahan jumlah perusahaan dalam periode satu tahun terhadap tahun dasarnya. Perubahan nilai jumlah perusahan untuk pertumbuhan tiap tahunnya setidaknya mencerminkan potensi industri kreatif dalam perekonomian nasional. Semakin tinggi annual growth semakin baik potensinya dalam perekonomian. Sebaliknya, semakin rendah annual growth maka semakin kecil pula potensi pengembangan industri kreatif tersebut. Terlihat pada Gambar 4 dapat bahwa pertumbuhan jumlah perusahaan pada tahun 2009 sampai dengan tahun 2011.

Dari hasil pertumbuhan subsektor industri kreatif Bangkalan sebelumnya pada variabel jumlah tenaga kerja (Gambar 2) linier dengan PDB (Gambar 1) dan jumlah perusahaan (Gambar 4), hal ini dikarenakan selama ini industri

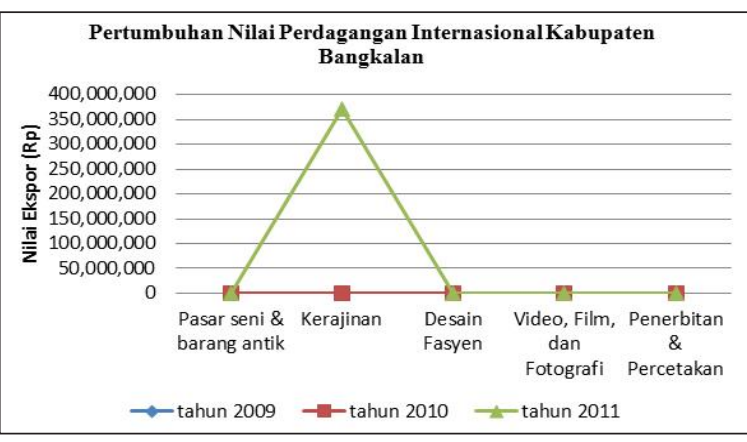

Gambar 3. Pertumbuhan Nilai Perdagangan Internasional Kabupaten Bangkalan

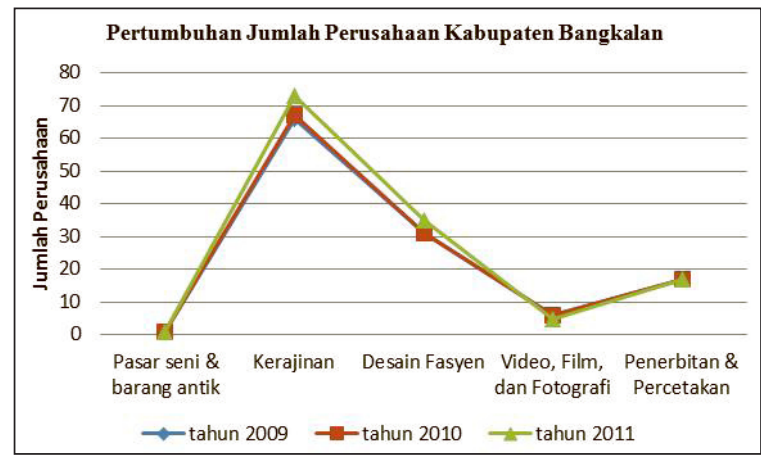

Gambar 4. Pertumbuhan jumlah perusahaan kabupaten Bangkalan 
kreatif Bangkalan masih berkembang dalam skala kecil menengah yang sistem produksi dan manajemennya berbasis home industry sehingga bilamana pesanan tinggi, maka tenaga kerja yang diberdayakan juga lebih banyak demikian sebaliknya bilamana tidak ada pesanan bisa jadi usaha kecil menengah tersebut gulung tikar. Selaras dengan Sumotarto (2010) bahwa untuk saat ini industri kreatif di Indonesia memiliki karakteristik memanfaatkan sumber daya alam, menggunakan teknologi madya atau tepat guna, serta sedapat mungkin bersifat padat karya dan lebih jauh oleh Darwanto (2012) Industri kreatif di beberapa negara memiliki persamaan dalam kontribusi penciptaan lapangan kerja serta kenaikan pendapatan daerah.

\section{Penentuan Kompetensi Inti Daearah}

Pembobotan kriteria keputusan dilakukan berdasarkan KBLI yang mencakup empat kriteria yaitu, produk domestik bruto,
Tabel 2. Hasil Pembobotan AHP

\begin{tabular}{ll}
\hline Variabel Pembobotan & Nilai Pembobotan \\
\hline PDB & 0,439 \\
Jumlah Ketenagakerjaan & 0,174 \\
Perdagangan Internasional & 0,169 \\
Jumlah Perusahaan & 0,219 \\
\hline
\end{tabular}

ketenagakerjaan, perdagangan internasional dan jumlah perusahaan. Hal ini berdasarkan hasil studi pemetaan industri kreatif Indonesia yang menyatakan bahwa kontribusi industri kreatif terhadap perekonomian Indonesia dapat dibedakan menjadi beberapa indikator seperti PDB, ketenagakerjaan, perdagangan internasional dan jumlah perusahaan (Departemen Perdagangan RI, 2007). Sehingga hirarki pembobotan kriteria keputusan berdasarkan variabel-variabel KBLI dengan menggunakan metode AHP (Analitycal Hierarchy Process) ditunjukkan pada Gambar 5.

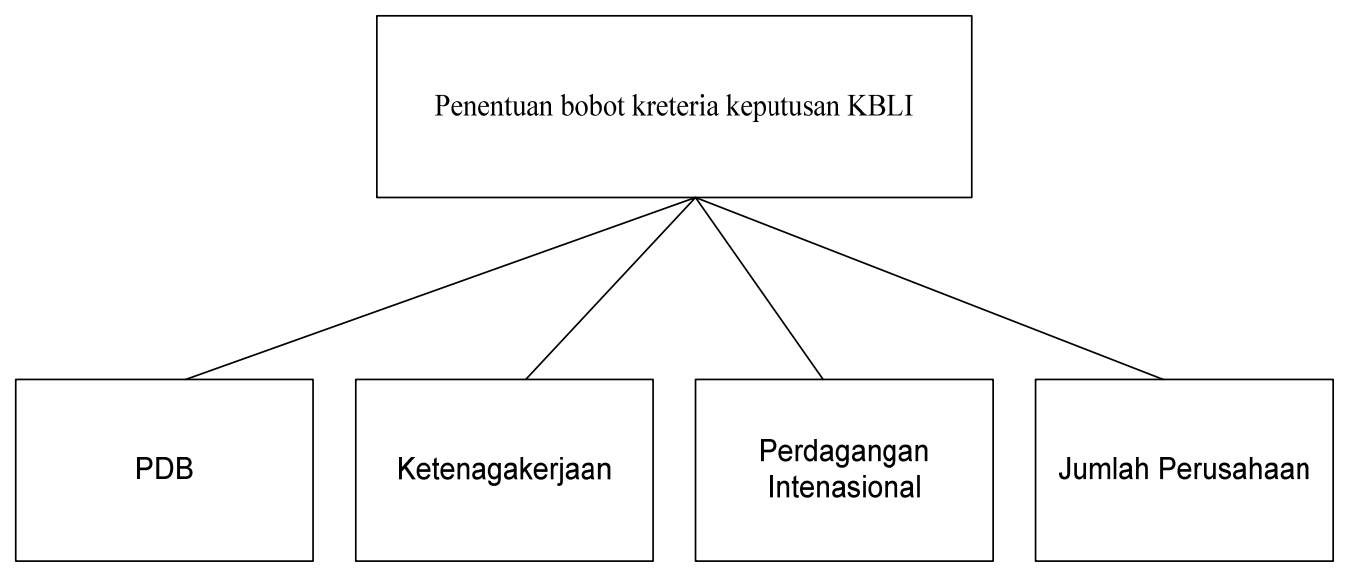

Gambar 5. Hirarki pembobotan kriteria keputusan

Tabel 3 Kontribusi nilai variabel KBLI industri kreatif

\begin{tabular}{ccccc}
\hline Variabel & PDB & Jumlah Pekerja & Perdagangan & Jumlah Perusahaan \\
\hline Kontribusi & Rp. 371.117 .500 & 568 & Rp. 149.280 .000 & 73 \\
\hline
\end{tabular}


Tabel 4. Preference Flow

\begin{tabular}{lccc}
\hline \multirow{2}{*}{ Alternatif sektor } & \multicolumn{3}{c}{ Preference Flow } \\
\cline { 2 - 4 } & Phi+ & Phi- & Phie \\
\hline $\begin{array}{l}\text { Pasar Seni dan } \\
\text { barang antik }\end{array}$ & 0,0000 & 0,3976 & $-0,3976$ \\
Kerajinan & 0,8460 & 0,0000 & 0,8460 \\
$\begin{array}{l}\text { Desain Fasyen } \\
\text { Video, Film, dan }\end{array}$ & 0,3223 & 0,1309 & 0,1914 \\
Fotografi & 0,0048 & 0,3782 & $-0,3734$ \\
$\begin{array}{l}\text { Penerbitan dan } \\
\text { Percetakan }\end{array}$ & 0,0476 & 0,3140 & $-0,2664$ \\
\hline
\end{tabular}

Data hasil pembobotan AHP yang diperoleh nilai dari masing-masing kriteria adalah PDB sebesar 0,439, jumlah tenaga kerja sebesar 0,174 , perdagangan internasional sebesar 0,169 , serta jumlah perusahaan sebesar 0,219. Dari uji konsistensi diperoleh nilai consistency ratio sebesar 0,06 $(<0,1)$ sehingga dapat disimpulkan bahwa jawaban responsden telah konsisten. Hasil ini menunjukkan bahwa variabel PDB memiliki tingkat kontribusi yang paling diprioritaskan terhadap pemilihan kompetensi inti daerah. Hal ini disebabkan karena PDB yang digunakan mencerminkan adanya nilai tambah produksi dan nilai tambah produksi yang baik memberikan menunjukkan produktivitasnya yang tinggi.

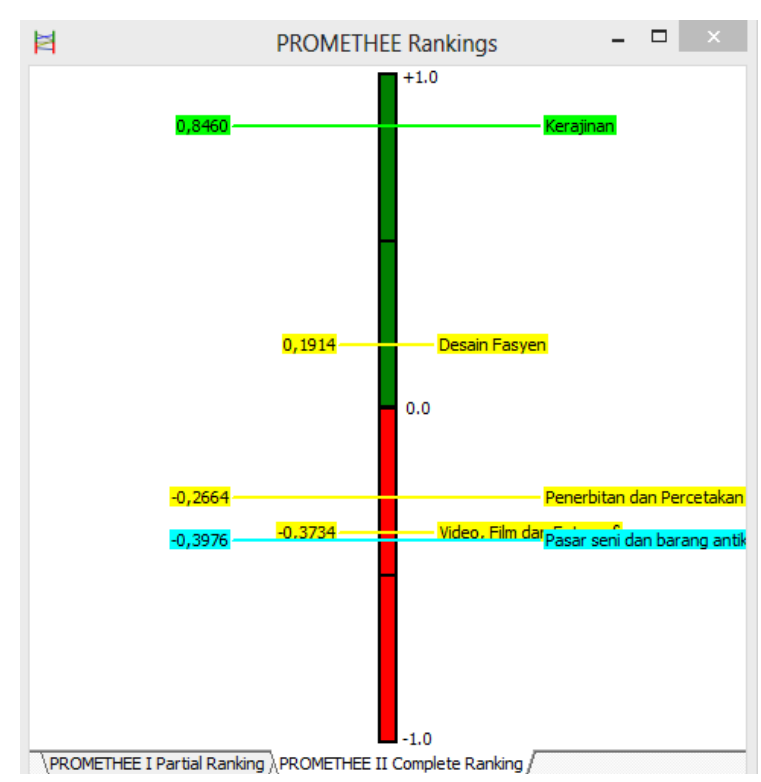

Gambar 6. Complete Ranking
Setelah pembobotan dilakukan kemudian dilakukan perankingan dengan PROMETHEE dengan mempertimbangkan nilai kontribusi empat variabel KBLI. Sedangkan hasil kontribusi nilai pada empat variabel yang dipetakan untuk PDB sebesar Rp. 371.117.500, jumlah pekerja sebanyak 568, nilai ekspor sebesar Rp. 149.280.000 dan jumlah perusahaan sebanyak 73 perusahaan sebagaimana Tabel 3, di mana data ini diperoleh dari hasil perhitungan pemetaan sebelumnya.

\section{Penentuan arah preferensi dan outranking}

Langkah ini arah preferensi dihitung baik berupa Leaving flow $\left(\varphi^{+}(\mathrm{a})\right)$, Entering flow $\left(\varphi^{-}(\mathrm{a})\right)$ dan Net flow ( $\varphi(\mathrm{a}))$. Semakin besar Leaving flow maka alternatif memiliki preferensi dipilih yang semakin besar. Perankingan didasarkan pada nilai Net flownya (Brans dan Mareschal, 1999). Hasil perhitungan Preference Flow yang diperoleh dari perhitungan dengan software Decision Lab 2000 seperti pada Tabel 4.

Dari Tabel 4 dapat dianalisis bahwa nilai leaving flow terbesar terdapat pada alternatif sektor kerajinan dengan nilai sebesar 0,8640 dan nilai enterring flow terendah juga terdapat pada alternatif sektor kerajinan dengan nilai sebesar 0,0000. Jadi nilai net flow yang terbesar yaitu kerajinan sebesar 0,8640 di dapat dari penjumlahan nilai leaving flow dengan entering flow. Jadi dapat disimpulkan sebagai alternatif pemilihan keputusan sektor yang sangat direkomendasikan untuk menjadi kompetensi inti daerah adalah sektor kerajinan.

Urutan perankingan berdasarkan hasil complete rangking dari software Decision Lab 2000 seperti pada Gambar 6. Urutan ranking menggambarkan prioritas yang dipilih, di mana pada hasil PROMETHEE diperolah urutan perankingan dimulai dari subsektor kerajinan, disusul oleh subsektor desain fesyen, penerbitan dan percetakan, video/film dan pasar seni dan barang antik.

Indahsari (2010) menyatakan bahwa kompetensi inti daerah dapat digunakan untuk 
menentukan produk andalan dengan cara mengetahui jenis Usaha Kecil Menengah (UKM) dalam konteks ini adalah subsektor industri kreatifnya. Dari visualisasi Gambar 6 diperoleh bahwa posisi subsektor kerajinan yang dipilih sebagai kompetensi inti daerah yang diunggulkan sebagai potensi daerah yang potensial dengan mempertimbangkan kriteria majemuk. Hal ini mengindikasikan bahwa subsektor kerajinan yang terdiri dari jenis industri kreatif berupa emban cincin, gedek, kusen kayu, kerajinan batuan, pecut, perahu kayu, perhiasan, mebel dan tikar adalah jenis kerajinan yang perlu diberikan prioritas pengembangan sebagai ikon produk unggulan daerah.

\section{SIMPULAN}

Hasil pemetaan profil dan jenis industri kreatif di Kabupaten Bangkalan berupa (1) pasar barang seni dan antik seperti souvenir, (2) kerajinan seperti ; emban cincin, gedek, kusen kayu, kerajinan batuan, pecut, perahu kayu, perhiasan, mebel, tikar (3) desain fesyen berupa ; batik, konveksi, bordir (4) Video, Film dan Fotografi seperti ; jasa pengadaan film, jasa cuci cetak (5) Penerbitan Percetakan. Kompetensi inti yang diunggulkan berdasarkan kriteria majemuk berupa Produk Domestik Bruto (PDB), jumlah ketenagakerjaan, perdagangan internasional dan jumlah perusahaan berdasarkan pembobotan AHP dan nilai kontribusi pada PROMETHEE di Kabupaten Bangkalan adalah subsektor kerajinan.

\section{DAFTAR PUSTAKA}

Brans, J.P., and Mareschal,B., 1999. Multiple Criteria Decision Analysis, Springer.
Cunningham, S., Cutler, T., Hearn, G., Ryan, M., and Keane, M., 2004. An Innovation Agenda for the Creative Industries: Where is the R\&D. Media International Australia: Incorporating Culture \& Policy, (112): pp. 174-185.

Darwanto, 2012. Penguatan Bisnis Kreatif Untuk Pengembangan Ekonomi Daerah ( Kasus; Penguatan Bisnis Kreatif Mebel Ukir Jepara), Proceeding Seminar dan Call For Papers Nasional I "Kewirausahaan \& Bisnis Kreatif, Semarang, ISBN 978-979-398.

Departemen Perdagangan RI, 2007. Studi Pemetaan Industri Kreatif.

Departemen Perdagangan RI, 2008. Pengembangan Ekonomi Kreatif Indonesia 2025: Rencana Pengembangan Ekonomi Kreatif Indonesia 20092015.

Huda, N., Agustina, F., dan Ansori, N., 2013. Pemetaan Potensi dan Penentuan Industri Kreatif Unggulan di Kabupaten Sumenep Madura, Robust Jurnal Teknik Industri, 1(2), pp. 71-78.

Indahsari, K. 2010. Model Penentuan Kompetensi Inti Industri Daerah (Studi Kasus Kabupaten Bangkalan), Jurnal Iqtishoduna, 6 (1).

Liang, S. C. I., 2013. Industri Kreatif dan Ekonomi Sosial di Indonesia: Permasalahan dan Usulan Solusi Dalam Menghadapi Tantangan Global, Prosiding The $5^{\text {th }}$ International Conference on Indonesian Studies: "Ethnicity and Globalization”, Yogyakarta, ISSN 2087-0019

Nurcahyo, R., Farizal, Stiadi, E., dan Saparudin, 2012. Penentuan dan Pengembangan Kompetensi Inti Kabupaten Bekasi, Jurnal Teknik Industri, 13 (1), pp. 37-42.

Pono, M., 2010. Strategi Pengembangan Kompetensi Inti Industri Daerah Kabupaten Tojo Una-Una Sulawesi Tengah, Skripsi, Fakultas Ekonomi Universitas Hasanudin, Makasar.

Sumotarto, U. 2010. Industri Kreatif Berbasis Sumber Daya Alam. Simposium Nasional Menuju Purworejo Dinamis dan Kreatif. Badan Pengkajian dan Penerapan Teknologi (BPPT), Jakarta. 